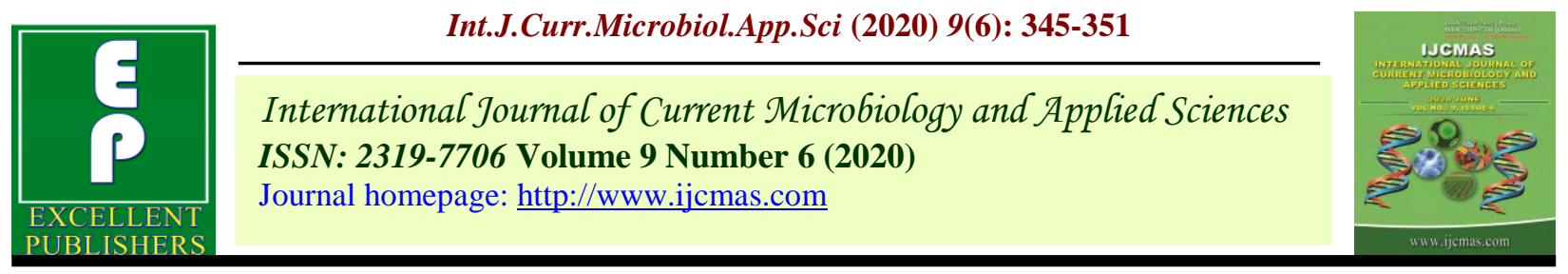

Original Research Article

https://doi.org/10.20546/ijcmas.2020.906.045

\title{
Enhance Banana Production with Application of Fertigation and Plastic Mulching in North Bihar Agro - Climatic Condition
}

\author{
S. K. Nirala* and R. Suresh \\ Precision Framing Development Center, Department of Soil \& Water Engineering \\ College of Agricultural Engineering, Dr. Rajendra Prasad Central Agricultural University, \\ Pusa, Bihar (Samastipur), India \\ *Corresponding author
}

Ke y w o r d s
Fertigation, plastic
mulching, Drip
irrigation, Yield of
Banana and B/C
ratio

\section{A B S T R A C T}

Present study is based on three years research trials to evaluate the effect of Fertigation and Plastic Mulching on Banana crop. Field trials accomplished total five treatments, i'e $\mathrm{T}_{1}(80 \% \mathrm{RDF}+0.8 \mathrm{~V}$ volume of water through drip irrigation+ mulch $), \mathrm{T}_{2}(80 \% \mathrm{RDF}+0.6 \mathrm{~V}$ volume of water through drip irrigation+ mulch $), \mathrm{T}_{3}(80 \% \mathrm{RDF}+0.8 \mathrm{~V}$ volume of water through drip irrigation without mulch), $\mathrm{T}_{4}(80 \% \mathrm{RDF}+0.6 \mathrm{~V}$ volume of water through Drip irrigation without mulch) and control treatment $\mathrm{T}_{5}(100 \% \mathrm{RDF}+$ flood irrigation) with four replications. The results revealed that the reproductive parameters such as average number of fingers per bunch, average weight per finger, average yield ( $\mathrm{kg} / \mathrm{bunch})$ and average yield (t/ha) was found in treatment $\mathrm{T}_{1}$ to the tune of $132.31,219.95 \mathrm{~g}, 28.15 \mathrm{Kg}$ and $94.87 \mathrm{t} / \mathrm{ha}$ followed by treatment $\mathrm{T}_{3} 124.28,211.79 \mathrm{~g}, 25.52 \mathrm{Kg}$ and $85.88 \mathrm{t} / \mathrm{ha}$. In control treatment $\mathrm{T}_{5}$ it was $103.75,183.72 \mathrm{~g}, 18.05 \mathrm{Kg}$ and $65.550 \mathrm{t} / \mathrm{ha}$, respectively. The benefit cost ratio was also estimated to be height in treatment $\mathrm{T}_{1}$ i'e 2.66 while in control treatment $\mathrm{T}_{5}$ it was 1.65 .

\section{Introduction}

Banana (Musa sp.) is the second most important fruit crop in India next to mango. Its year round availability, affordability, varietal range, taste, nutritive and medicinal value makes it the favourite fruit among all classes of people. It has also good export potential. Hi-tech cultivation of the crop is an economically viable enterprise leading to increase in productivity, improvement in produce quality and early crop maturity with the produce commanding premium price. Banana and plantains are grown in about 120 countries.

Total annual world production is estimated at 86 million tonnes of fruits. India leads the world in banana production with an annual output of about 14.2 million tonnes. 
Other leading producers are Brazil, Eucador, China, Phillipines, Indonesia, Costarica, Mexico, Thailand and Colombia. In India banana ranks first in production and third in area among fruit crops. It accounts for $13 \%$ of the total area and $33 \%$ of the production of fruits. Production is highest in Maharashtra (3924.1 thousand tones) followed by Tamil Nadu (3543.8 thousand tones).

Within India, Maharashtra has the highest productivity of 65.70 metric t/ha against national average of 30.5 tones/ha, whereas the average yield in Bihar is very less it is about $20 \mathrm{t} / \mathrm{ha}$. This might be due to inappropriate package and practices regarding the irrigation and fertigation. The other major banana producing states are Karnataka, Gujarat, Andhra Pradesh and Assam.

Drip irrigation is a controlled method of irrigation, consisting of tubes with emitters. It allows increasing water use efficiencies by providing precise amounts of water directly to the root zone of individual plants (Burt and Styles, 2007). Banana is a perennial crop, depending up on age of plant and climatic parameters, the water requirement varied from 2 lit per plant per day to 8.00 lit per plant per day. The quantity of water requirement per plant per day vaired from 2.3 to 6.7 liter depending on the stage of crop and weather condition Srivanappan et at. (1987).

Fertigation is a technology for application of fertilizer to the crops along with irrigation water through drip or sprinkler irrigation on a continual basis in controlled manner as so as to allow for steady uptake of nutrients by plants and to effect saving in costly inputs of both water and fertilizer (Patel and Rajput 2011). Fertilizer and water use in trickler fertigated potato using different fertilizer application rates, frequencies of application and wetted soil volume were compared with a furrow irrigated and conventionally fertigated crop (Chawla and Narda 2001), results indicated that water and fertilizer saving to the extent of 30 and $70 \%$ respectively with comparable yield levels. Highest yield of $36.29 \mathrm{t} / \mathrm{ha}$ of fresh tubers was obtained under trickle irrigation as compared to $21.5 \mathrm{t} / \mathrm{ha}$ for the furrow irrigated crop.

An experiment was conducted to determine the effect of water soluble fertilizer through drip irrigation on the growth and yield of banana, during 1998 -2000 at Rahuri (Singh 2000). The banana yield was significantly higher with increase in the level of fertilizer and was found maximum $68 \mathrm{t} / \mathrm{ha}$ under 100 percent recommended dose. Studies were undertaken to assess the effects of fertigation through drip on the growth, yield and quality of banana during 1997-98 with twelve treatments comprising 2 fertilizer sources, 3 fertilizers levels and two planting system.

These treatments were also compared with surface irrigation methods using straight fertilizers application (Pawar et al., 2001). The results revealed that the banana fruit yield was significantly higher in normal planting (82.86t/ha) than paired row planting $(75.75$ $\mathrm{t} / \mathrm{ha}$ ). The fruit yield increased significantly in water soluble fertilizers $(81.01 \mathrm{t} / \mathrm{ha})$ as compared to only $\mathrm{N}$ through drip (77.59 t/ha).

Mulching in general is a beneficial practice for crop production. Mulch conserves soil moisture, retains heat as well as it suppress weed growth (Chakarborthy and Sadhu 1994 and Hooda et al., 1999). Polyethylene mulches are widely used in vegetables and horticultures crop and have contributed significantly to reduction of losses due to weed competition (Nguajio and Ernest, 2004).

Film color also affects effective weed seed germination, growth and development under the plastic (Brault et al., 2002). 


\section{Materials and Methods}

\section{Study area}

The experiment was carried out at Dr Rajendra Prasad Central Agricultural University Pusa Samastipur Bihar under "Precision Farming Development Centre (PFDC)" financed by the National Committee on Plasticulture Application in Agriculture and Horticulture (NCPAH), Ministry of Agriculture and Farmers Welfare, GoI, New Delhi, running in the Department of Soil \& Water Engineering, College of Agricultural Engineering, Pusa, Samastipur. It is situated at $25^{\circ} 59^{\prime} \mathrm{N}$ latitude and $85^{\circ} 48^{\prime} \mathrm{E}$ longitude. Altitude of the site is $52.92 \mathrm{~m}$ above mean sea level. Experimental site is under humid subtropical climate, greatly influenced by the south-west monsoon. The main characteristic of the climate is hot-dry summer followed by cold winters. Average annual rainfall is 1270 $\mathrm{mm}$, out of which about $1026 \mathrm{~mm}$ is received during the monsoon season from June to October. Soil type is sandy clay loam with average available moisture content $12.01 \%$.

The experiment consists of five treatment viz., with combination of $80 \%$ RDF and two level of irrigation. $100 \%$ RDF with flood irrigation was consider as control treatment. The experiment was conducted for the duration of three years.

\section{Land preparation and Planting of banana}

The field preparation for banana plantation was carried out by two ploughings with mould board plough followed by cross harrowing to make the soil porous. The pits of $60 \mathrm{~cm} \times 60 \mathrm{~cm} \times 60 \mathrm{~cm}$ sizes were dug at $2 \mathrm{~m}$ $\mathrm{x} 1.5 \mathrm{~m}$ spacing. Before transplanting the banana plantlets, FYM, mustared cake and MOP were mixed in the soil at the rate of 10 $\mathrm{kg}, 1 \mathrm{~kg}, 200 \mathrm{~g}$ per plant, respectively and filled in the pits. Filled pit were left for 15 days to get decompose and mix the manure/fertilizers in the soil thoroughly.

\section{Treatments}

Plant geometry: $2.0 \mathrm{~m} \mathrm{x} 1.5 \mathrm{~m}$

$\mathrm{T} 1(80 \% \mathrm{RDF}+0.8 \mathrm{~V}$ volume of water through drip irrigation+ mulch)

$\mathrm{T} 2(80 \% \mathrm{RDF}+0.6 \mathrm{~V}$ volume of water through drip irrigation+ mulch)

$\mathrm{T} 3$ (80\% RDF+0.8V volume of water through drip irrigation without mulch)

$\mathrm{T} 4$ (80\% RDF+0.6V volume of water through Drip irrigation without mulch)

T5 (100\%RDF+flood irrigation)

Design : RBD

Replication : 3

Crop: Banana

Variety: (Grand Naine)

Trial Period: Start- July, 2008 - End: Dec. 2011

\section{Drip irrigation}

Drip system consisting of sand filter $10 \mathrm{~m}^{3} / \mathrm{h}$ as discharge capacity; $50 \mathrm{~mm}$ nominal size; 2 $\mathrm{kg} / \mathrm{cm}^{2}$ nominal pressure with 14-24 mesh; screen filter of $10 \mathrm{~m}^{3} / \mathrm{h}$ discharge capacity; 65 $\mathrm{mm}$ of nominal size; $2 \mathrm{~kg} / \mathrm{cm}^{2}$ nominal pressure with 120 mesh as the screen size), pipe line (main $-63 \mathrm{~mm}$ diameter and $21 \mathrm{~m}$ length; and sub-main - $63 \mathrm{~mm}$ diameter and $11 \mathrm{~m}$ as length) and drippers (4 lph) was installed/used under experiment. Cavity type tube well of 2.5 inch diameter suction pipe was used as the water source. A 7.5 HP diesel pump set was used to suck the water from well and supply to the pipe line system through filters. The main and sub-main pipe line was installed at $40 \mathrm{~cm}$ depth from the ground surface. Laterals were installed over the ground surface, row wise passing through banana plantlets below plastic mulch. Drippers were placed on the lateral near banana plantlets. 
During system operation, the water first goes to the main pipeline, to the sub-main pipeline, to the laterals and lastly to the ground near banana plantlets through drippers.

\section{Mulch}

Mulching was performed after one month of banana transplantation. For which, the banana plant rows were formed in the ridge shape of nominal size with outward slope. The laterals equipped with drippers are placed over the ridge shape banana row.

After that as per layout, the silver and block colours polythene sheets of 60 micron (0.06) thickness were spread over the ridge. The edges of polythene were covered with the help of loose soil.

\section{Crop water requirement}

The daily crop water requirement of banana plant was determined by using the method suggested by NCPH, Ministry of Agriculture, New Delhi (Anonymous, 1997). The formula of crop water requirement is given as under:

$\mathrm{V}=\mathrm{E}_{\mathrm{p}} \cdot \mathrm{K}_{\mathrm{c}} \cdot \mathrm{K}_{\mathrm{p}} \cdot \mathrm{W}_{\mathrm{p}} \cdot \mathrm{A}$

Net volume of water $\mathrm{Vn}$, could be expressed as,

$\mathrm{V}_{\mathrm{n}}=\mathrm{V}-\mathrm{R}_{\mathrm{e}} \cdot \mathrm{A}$

The total volume of water applied per plant per day is given by, $=\mathrm{V}_{\mathrm{n}} \mathrm{x}$ no. of plant

Where, $\mathrm{V}=$ Water requirement of consumptive use of plant (1/plant/day),

$\mathrm{V}_{\mathrm{n}}=$ net volume of water, $\mathrm{E}_{\mathrm{p}}=$ pan evaporation $(\mathrm{mm} /$ day $), \quad \mathrm{K}_{\mathrm{c}}=$ crop coefficient, $\quad \mathrm{K}_{\mathrm{p}}=$ pan factor, $\mathrm{W}_{\mathrm{p}}=$ wetted area factor, $A=$ spacing of the plant $\left(\mathrm{m}^{2}\right), \mathrm{R}_{\mathrm{e}}$ $=$ effective rainfall $(\mathrm{cm})$
In equation 1 the daily pan evaporation values were collected from meteorological observatory located in crop research centre (CTRI - Old name) Pusa Farm, Samastipur, Bihar for banana crop period (March, 2009 to March, 2011). The pan factor $\left(K_{p}\right)$ was taken as 0.8 for USWB type pan (Anonymous 1997). The wetted area factor $\left(W_{p}\right)$ was considered as 0.9 for initial stage and 1 for full growth stage (anonymous, 1997). The value of crop co-efficient $\left(\mathrm{K}_{\mathrm{c}}\right)$ was taken as 0.8 for initial stage and 1 for full growth stage of banana plants (Anonymous, 1997).

\section{Fertilizer dose}

The recommended dose of fertilizers for banana crop is $200 \mathrm{~g}$ nitrogen, $50 \mathrm{~g}$ phosphorus and $300 \mathrm{~g}$ potash per plant per year. The phosphorus and potash were applied as basal application in two split doses, i.e. first dose at 90 DAT ( $6^{\text {th }}$ May) and second dose at 180 DAT ( $7^{\text {th }}$ August). The nitrogen was applied at month interval through fertigation, before commencement of flowers in banana plants.

\section{Results and Discussion}

\section{Plant height, girth and plant canopy}

The biometrical parameters of banana plants such as plant height, girth, plant canopy etc under different treatments presented in table 1. Data revealed significantly maximum plant growth in terms of height $(2.04 \mathrm{~m})$, plant girth $(53.69 \mathrm{~cm})$ and canopy spread $(4.15 \mathrm{sqm})$ with the treatment $\mathrm{T}_{1}(80 \% \mathrm{RDF}+0.8 \mathrm{~V}$ volume of water through drip irrigation+ mulch). This was followed by $\mathrm{T}_{3}(80 \% \mathrm{RDF}+0.8 \mathrm{~V}$ volume of water through drip irrigation+ without mulch) with plant height $1.96 \mathrm{~m}$; plant girth $52.14 \mathrm{~cm}$ and canopy spread $3.76 \mathrm{sq} \mathrm{m}$. In control treatment the plant height, girth and canopy spread was $1.45 \mathrm{~m}, 43.84 \mathrm{~cm}$ and 3.55 sqm respectively. 
Table.1 Effect of fertigation and mulch on biometrics of Banana

\begin{tabular}{|c|c|c|c|c|c|c|}
\hline Treatments & $\begin{array}{l}\text { Plant } \\
\text { height } \\
(\mathbf{m})\end{array}$ & $\begin{array}{l}\text { Plant } \\
\text { girth } \\
(\mathrm{cm})\end{array}$ & $\begin{array}{c}\text { Plant } \\
\text { Canopy } \\
\text { (sqm) }\end{array}$ & $\begin{array}{c}\text { Days } \\
\text { taken for } \\
\text { maturity }\end{array}$ & $\begin{array}{c}\text { Number of } \\
\text { Fingers/bunch }\end{array}$ & $\begin{array}{l}\text { Weight of } \\
\text { fingers (g) }\end{array}$ \\
\hline $\mathbf{T}_{1}$ & 2.04 & 53.69 & 4.15 & 306.85 & 131.51 & 215.64 \\
\hline $\mathbf{T}_{2}$ & 1.93 & 50.90 & 3.51 & 321.08 & 95.46 & 172.96 \\
\hline $\mathbf{T}_{3}$ & 1.96 & 52.14 & 3.76 & 313.02 & 124.30 & 206.64 \\
\hline $\mathbf{T}_{4}$ & 1.66 & 46.56 & 3.66 & 325.8 & 84.20 & 170.75 \\
\hline $\mathbf{T}_{5}$ & 1.45 & 43.84 & 3.55 & 336.02 & 109.50 & 187.26 \\
\hline CD & 0.91 & 1.28 & 0.076 & 10.41 & 7.61 & 6.64 \\
\hline SEm (s) & 0.03 & 0.42 & 0.024 & 3.76 & 2.74 & 2.39 \\
\hline
\end{tabular}

Table.2 Effect fertigation and mulch on yield of banana ( $\mathrm{kg} / \mathrm{bunch})$

\begin{tabular}{|c|l|l|l|l|}
\hline Treatments & $\mathbf{2 0 0 9 - 1 0}$ & $\mathbf{2 0 1 0 - 1 1}$ & $\mathbf{2 0 1 1 - 1 2}$ & $\begin{array}{l}\text { Average Yield } \\
\text { (kg)/ bunch }\end{array}$ \\
\hline $\mathbf{T}_{\mathbf{1}}$ & 28.49 & 27.60 & 28.36 & 28.15 \\
\hline $\mathbf{T}_{\mathbf{2}}$ & 16.71 & 16.52 & 16.51 & 16.58 \\
\hline $\mathbf{T}_{\mathbf{3}}$ & 25.80 & 25.07 & 25.68 & 25.52 \\
\hline $\mathbf{T}_{\mathbf{4}}$ & 14.72 & 14.21 & 14.38 & 14.44 \\
\hline $\mathbf{T}_{\mathbf{5}}$ & 18.91 & 18.20 & 20.51 & 19.21 \\
\hline $\mathbf{C . D}$ & 1.006 & 1.69 & 1.02 & \\
\hline $\mathbf{S E m}(\mathbf{s})$ & 0.33 & 0.58 & 0.35 & \\
\hline $\mathbf{C . V}(\mathbf{\%})$ & 8.26 & 14.09 & 8.8 & \\
\hline
\end{tabular}

Table.3 Effect fertigation and mulch on yield of banana (t/ha)

\begin{tabular}{|c|l|l|l|l|}
\hline Treatments & $\mathbf{2 0 0 9 - 1 0}$ & $\mathbf{2 0 1 0 - 1 1}$ & $\mathbf{2 0 1 1 - 1 2}$ & $\begin{array}{l}\text { Average yield } \\
\text { (t/ha })\end{array}$ \\
\hline $\mathbf{T}_{\mathbf{1}}$ & 94.95 & 95.15 & 94.52 & 94.87 \\
\hline $\mathbf{T}_{\mathbf{2}}$ & 55.69 & 56.10 & 55.03 & 55.61 \\
\hline $\mathbf{T}_{\mathbf{3}}$ & 85.99 & 86.05 & 85.60 & 85.88 \\
\hline $\mathbf{T}_{\mathbf{4}}$ & 49.06 & 49.70 & 47.93 & 48.90 \\
\hline $\mathbf{T}_{\mathbf{5}}$ & 63.68 & 64.60 & 68.37 & 65.55 \\
\hline $\mathbf{C . D}$ & 3.08 & 3.62 & 4.41 & \\
\hline $\mathbf{S E m}(\mathbf{s})$ & 1.03 & 1.21 & 1.46 & \\
\hline $\mathbf{C .} \mathbf{V}(\mathbf{\%})$ & 8.72 & 10.14 & 12.26 & \\
\hline & & & & \\
\hline
\end{tabular}




\section{Average number of fingers and average weight of fingers}

Table 1 also revealed that the treatment $\mathrm{T} 1$ has taken 306.85 days about 30 days less time to maturity as compare to control treatment T5 336.02 days, where as in treatment T3 it has 313.02 days. Number of banana fingers was maximum in treatment T1 i.e. 131.51 per bunch which is about $16.91 \%$ greater than control treatment $\mathrm{T} 2$, it was 109.50 , while in number of finger in $\mathrm{T} 3$ was 124.30. The effect of fertigation on weight of Banana finger was also recorded, which revealed that the maximum average weight of finger was in T1 $215.64 \mathrm{~g}$, followed by T3 206.64g, where as in control treatment it was $187.26 \mathrm{~g}$.

\section{Yield}

The highest bunch weight $(28.15 \mathrm{~kg})$ was recorded under $T_{1}$ followed by $T_{3}(80 \%$ $\mathrm{RDF}+0.8 \mathrm{~V}$ volume of water through drip irrigation+ without mulch) with $25.52 \mathrm{~kg}$ bunch weight. Minimum bunch weight 14.44 $\mathrm{kg}$ was noted at $\mathrm{T}_{4}(80 \% \mathrm{RDF}+0.6 \mathrm{~V}$ volume of water through Drip irrigation without mulch) where as in control treatment it was recorded as $19.21 \mathrm{~kg}$.

As per yield is concerned the height yield recorded in treatment $\mathrm{T} 194.87 \mathrm{t} / \mathrm{ha}$, which is about 44.72 greater than the control. In case of treatment T3 the yield was recorded as $85.61 \mathrm{t} / \mathrm{ha}$, which is $31.00 \%$ higher than control. In control the average yield was recorded as $65.55 \mathrm{t} / \mathrm{ha}$. Thus the significant effect of fertigation and mulching was found treatment $\mathrm{T} 1$.

\section{Economics}

It has been found that, the treatment $\mathrm{T} 1$ resulted highest b/c ratio i'e 2.66, while in control treatment it was found as 1.65 . In case of treatment $\mathrm{T} 1$, the net seasonal income was high to the tune of R. 158601.00 per ha, where as in control treatment T5 was Rs. 93965.00 per ha. The fertigation which combines irrigation with fertilizers is the most effective and convenient means of maintaining optimum fertility level and water supply according to the specific requirement of crops with drip system.

Drip irrigation is the precise water application method which saves water by reducing the size of wet soil surface and thus decreasing the amount of direct evaporation and excess water percolation from the root zone. On the basis of data recorded and analysed under different treatments the pertinent findings with respect to different objectives under taken, are concluded below:

The height plant growth was found under T1 $(80 \% \mathrm{RDF}+0.8 \mathrm{~V}$ volume of water through drip irrigation+ mulch) followed by $\mathrm{T} 3 \quad(80 \% \quad \mathrm{RDF}+0.8 \mathrm{~V}$ volume of water through drip irrigation+ without mulch).

The treatment $\mathrm{T} 1(80 \% \mathrm{RDF}+0.8 \mathrm{~V}$ volume of water through drip irrigation+ without mulch) also produced higher yield (94.87 t/ha) which is about 44.72 greater than the control followed by T3 was recorded as $85.61 \mathrm{t} / \mathrm{ha}$, which is $31.00 \%$ higher than control. In control the average yield was recorded as $65.55 \mathrm{t} / \mathrm{ha}$.

In order to achieved the yield at par with conventional method, there is need of only $64 \%$ fertilizer of recommended dose in Banana cultivation, revealing thus a saving (Chopade et al., 1998) of about $35 \%$ fertilizers due to fertigation through dip.

The benefit cost ratio was estimated heightest in treatment $\mathrm{T}_{1} \mathrm{i}$ 'e 2.66 while in control treatment $\mathrm{T}_{5}$ it was 1.65 . 


\section{Acknowledgements}

The authors gratefully acknowledge to the National Committee on Plasticulture Applications in Horticulture (NCPAH), Ministry of Agriculture \& Farmers Welfare, Govt. of India which provide the fund for conducting the experiment under PFDC.

\section{References}

Anonymous (1997).Training manual on use of plastic in agriculture, NCPAH, Ministry of agriculture, New Delhi

Brault, D., Stewart, K.A and Jenni, S.(2002). Optical properties of paper and polyethylene mulches used for weed control in lettuce. HortScience, 37: 8791.

Burt, C.M. and S. W. Styles. 2007. Drip and Micro Irrigation Design and Management for Trees, Vines, and Field Crops. 3rd Edition. Irrigation Training and Research Center, 2007.

Chakraborty, R.C., and Sidhu, M.K.(1994). Effect of mulch type and color on growth and yield of tomato. Indian Journal of Agricultural Science, 64: 608-612.

Chawla, J.K and Narda, N.K.(2001). Economy in water and fertilizer use in trickle fertigated potato. Journal of Irrigation and Drainage 50 (2): 129-37.

Chopade, S.O., Bansode, P.N and Hiwase, S.S (1998). Studies of fertilizer and water a management on onion. P.K.V. Res. J. 22 (1): pp 44-47.

Hooda, R.S., Singh, J., Malik, V.S and Batra, v.k (1999). Influence of direct seeding, transplanting time and mulch on tomato yield, Vegetable Science, 26(2):140142.

Patel, N and Rajput, T.B.S.(2011). Drip Irrigation p183.. Directorate of Knowledge Management in Agriculture, Indian Council of Agricultural Research. Krishi Anusandhan Bhavan, New Delhi Sivanappan, R.K., Kuumar, O.P and Kumar, V.(1987) Drip irrigation. Keerthi Publication House (P.) Ltd. Combatore.

Pawar, D.D., Raskar, B.S., Banger, A.R., Bhoi, P.G and Shinde, S.M.(2001). Effect of water soluble fertilizers through drip and planting techniques on growth, yield and quality of Banana.(In) Micro Irrigation, pp 515-9. Singh, H.P, Kaushik, S.P., Kumar, Aahwani., Murthy, T.S and Sameul Jose C (Eds).

Singh, S.R 2000. Annual Report for 19992000, Directorate of Water Management Research, Patna.

\section{How to cite this article:}

Nirala. S. K. and Suresh. R. 2020. Enhance Banana Production with Application of Fertigation and Plastic Mulching in North Bihar Agro - Climatic Condition. Int.J.Curr.Microbiol.App.Sci. 9(06): 345-351. doi: https://doi.org/10.20546/ijcmas.2020.906.045 